\title{
PENERAPAN METODE PICTURE AND PICTURE \\ DALAM MENINGKATKAN HASIL BELAJAR SISWA KELAS X AP3 \\ PADA MATA PELAJARAN PENDIDIKAN AGAMA ISLAM SEKOLAH MENENGAH KEJURUAN (SMK) VETERAN CIREBON
}

\author{
Uun Jamilatun Sadiyah, Nawawi \\ Fakultas Ilmu Tarbiyah dan Keguruan \\ Institut Agama Islam Negeri Syekh Nurjati Cirebon \\ Email: uunjamilatun@gmail.com
}

\begin{abstract}
ABSTRAK
Berdasarkan pengamatan yang penulis lakukan selama Praktik Pengalaman Lapangan (PPL) pada tanggal 27 September 2016 terhadap proses belajar mengajar pada mata pelajaran Pendidikan Agama Islam (PAI) di kelas X AP3 SMK Veteran Cirebon, guru sudah berusaha maksimal dalam menyampaikan materi dengan baik, tetapi keinginan atau hasil belajar siswa masih kurang pada pembelajaran PAI dikarenakan metode yang diterapkan hanya ceramah yang menyebabkan siswa hanya duduk diam, mendengar, mencatat dan menghafal dan tidak dibiasakan untuk belajar aktif, selain itu masih ditemukan siswa yang memiliki nilai dibawah Kriteria Ketuntasan Minimal (KKM).

Penelitian ini bertujuan untuk mengetahui hasil belajar siswa kelas X AP3 Sekolah Menengah Kejuruan (SMK) Veteran Cirebon sebelum dan sesudah menggunakan Metode Picture And Picture dan apakah ada peningkatan hasil belajar pada pembelajaran PAI setelah meggunakan Metode Picture And Picture.

Metode Pembelajaran Picture And Picture siswa diperlakukan sebagai subjek pembelajaran secara aktif, pembelajaran ini merupakan suatu pembelajaran yang lebih menitik beratkan pada upaya pemberdayaan peserta didik pada saat melaksanakan proses pembelajaran. Metode Picture And Picture sebagai segala sesuatu yang dapat digunakan untuk menyalurkan pesan (message) merangsang pikiran, perasaan perhatian, dan kemauan siswa sehingga dapat mendorong proses belajar. Sedangkan hasil belajar siswa sendiri adalah

Al-Tarbawi Al-Haditsah: Jurnal Pendidikan Islam

Vol. 2, No. 2, Desember 2017
\end{abstract}


kemampuan yang diperoleh siswa setelah melalui kegiatan belajar. Untuk mengetahui hasil belajar yang dicapai telah sesuai dengan tujuan yang dikehendaki melalui evaluasi

Penelitian menggunakan metode deskriptif kuantitatif dengan Teknik pengumpulan data, dalam penelitian ini menggunakan tes, kuesioner (angket), observasi, dokumentasi dan wawncara. Teknik analisis data melalui dua tahap yaitu analisis deskriptif dan analisa product moment. Subjek penelitian adalah siswa kelas X AP3, guru mata pelajaran Pendidikan Agama Islam (PAI), dan beberapa guru lainnya.

Hasil penelitian menunjukan bahwa: 1) hasil belajar siswa kelas X AP3 sebelum menggunakan Metode Picture And Picture dalam kategori sedang dengan rata-rata nilai 60. 2) hasil belajar siswa kelas X AP3 sesudah menggunakan Metode Picture And Picture terdapat peningkatan dengan rata-rata nilai 87 termasuk dalam kategori tinggi. 3) adanya korelasi atau pengaruh Metode Picture And Picture terhadap peningkatan hasil belajar siswa kelas $X$ AP3 sekolah Menengah Kejuruan (SMK) Veteran Cirebon.

\section{Kata Kunci: Metode Picture And Picture Dan Hasil Belajar}




\section{A. Pendahuluan}

Pendidikan merupakan salah satu bentuk perwujudan kebudayaan manusia yang dinamis dan syarat perkembangan. Oleh karena itu, perubahan atau perkembangan pendidikan adalah hal yang memang seharusnya terjadi sejalan dengan perubahan budaya kehidupan. Perubahan dalam arti perbaikan pendidikan pada semua tingkat perlu terus-menerus dilakukan sebagai antisipasi kepentingan masa depan.

Pendidikan yang mampu mendukung pembangunan di masa mendatang adalah pendidikan yang mampu mengembangkan potensi peserta didik, sehingga yang bersangkutan mampu menghadapi dan memecahkan problema kehidupan yang dihadapinya. Pendidikan harus menyentuh nurani maupun potensi kompetensi peserta didik. Konsep pendidikan tersebut terasa semakin penting ketika seseorang harus memasuki kehidupan di masyarakat dan dunia kerja, karena yang bersangkutan harus mempu menerapkan apa yang dipelajari di sekolah untuk menghadapi problema yang dihadapi dalam kehidupan sehari-hari saat ini maupun yang akan datang. ${ }^{1}$

Kegiatan belajar mengajar diartikan sama dengan proses belajar megajar, merupakan operasional dari kurikulum atau GBPP yang diberikan kepada siswa sesuai jenjang pendidikan, kesemuanya dalam upaya mencapai tujuan pendidikan nasional yang dimuat dalam Undang-Undang No. 20 tahun 2003, yang berbunyi:

Pendidikan nasional berfungsi mengembangkan kemampuan dan membentuk watak serta peradaban yang bermartabat dalam rangka mencerdaskan kehidupan bangsa, bertujuan untuk berkembangnya potensi peserta didik agar menjadi manusia yang beriman dan bertaqwa kepada Tuhan yang Maha Esa, berakhlak mulia, sehat, berilmu, cakap, kreatif, mandiri dan menjadi warga negara yang demokratis serta bertanggung jawab. ${ }^{2}$

\footnotetext{
${ }^{1}$ Trianto, Mendesain Model Pembelajaran Inovatif-Progresif (Jakarta: Kencana, 2011),
} $2-3$.

2 Undang-undang SISDIKNAS (Sistem Pendidikan Nasional ) no 20 Th 2003, 2011 (Jakarta: Sinar Grafika, 2011), 7. 
Belajar adalah suatu proses usaha yang dilakukan seseorang untuk memperoleh suatu perubahan yang baru sebagai hasil pengalamannya sendiri dalam interaksi dengan lingkungannya. Sedangkan, Hakim (2002), mengartikan belajar adalah suatu proses perubahan di dalam kepribadian manusia, dan perubahan tersebut ditampakan dalam bentuk peningkatan kualitas dan kuantitas tingkah laku seperti peningkatan kecakapan, pengetahuan, sikap, kebiasaan, pemahaman, keterampilan, daya fikir, dan lain-lain kemampuannya.

Menurut Salfin mengatakan belajar secara umum diartikan sebagai perubahan pada individu yang terjadi melalui pengalaman, dan bukan karena pertumbuhan atau perkembangan tubuhnya atau kakteristik seseorang sejak lahir. Manusia banyak belajar sejak lahir dan bahkan ada yang berpendapat sebelum lahir. Proses belajar terjadi melalui banyak cara baik disengaja maupun tidak disengaja dan berlangsung sepanjang waktu menuju pada suatu perubahan pada diri pembelajar. Perubahan yang dimaksud adalah perubahan perilaku tetap berupa pengetahuan, pemahaman, keterampilan, dan kebiasaan yang baru diperoleh individu. Sedangkan pengalaman merupakan interaksi antara individu dengan lingkungan sebagai sumber belajarnya. Jadi, belajar disini diartikan sebagai proses perubahan perilaku tetap dari belum tahu menjadi tahu, dari tidak paham menjadi paham, dari kurang terampil menjadi terampil, dan dari kebiasaan lama menjadi kebiasaan baru, serta bermanfaat bagi lingkungan maupun individu itu sendiri. ${ }^{3}$

Keberhasilan proses pembelajaran tidak terlepas dari kemampuan guru mengembangkan model-model pembelajaran yang berorientasi pada peningkatkan intensitas keterlibatan siswa secara efektif di dalam proses pembelajaran. Pengembangan model pembelajaran yang tepat pada dasarnya bertujuan untuk menciptakan kondisi pembelajaran yang memungkinkan siswa dapat belajar secara aktif dan menyenangkan, sehingga siswa dapat meraih hasil belajar dan prestasi yang optimal. ${ }^{4}$

${ }^{3}$ Trianto, Mendesain model pembelajaran inovatif-progresif (Jakarta: PT Prenada Media Group, 2009), 16-17.

${ }^{4}$ Aunurrahman, Belajar dan pembelajaran (Pontianak: ALFABETA, 2009), 140. 
Secara teknis metode berarti prosedur yang dipakai untuk mencapai tujuan, metode juga diartikan sebagai prosedur yang dipergunakan pendidik dalam melaksanakan tugas-tugas kependidikan. Selain itu dapat juga diartikan sebagai teknik tertentu yang dipergunakan siswa untuk menguasai materi tertentu, atau cara yang dipakai untuk merumuskan aturan-aturan tertentu dari suatu prosedur. ${ }^{5}$

Sebagaimana telah disebutkan dalam konsep Islam yang terkandung dalam Q.S. An-Nahl ayat 125.

"Serulah (manusia) kepada jalan Tuhan-mu dengan hikmah dan pelajaran yang baik serta bantahlah mereka dengan cara yang baik. Sesungguhnya Tuhanmu Dialah yang lebih mengetahui siapa yang tersesat dari jalan-Nya dan Yang lebih mengetahui orang-orang yang mendapat petunjuk". 6 Jadi metode adalah suatu cara yang tersusun sistematis yang dipergunakan oleh guru untuk memudahkan dalam menyampaikan penjelasan materi.

Hasil belajar atau achievement merupakan realisasi atau pemekaran atau kecakapan-kecakapan potensial atau kapasitas yang dimilki seseorang. Penguasaan hasil belajar oleh seseorang dapat dilihat dari perilakunya, baik perilaku dalam bentuk penguasaan pengetahuaan, keterampilan berpikir maupun keterampilan motorik. ${ }^{7}$ Sedangkan menurut Nana sujana dalam hasil belajar adalah kemampuan yang dimilki siswa setelah ia menerima pengalaman belajarnya. Hasil belajar yang dicapai oleh siswa sangat erat kaitannya dengan belajar dan rumusan tujuan intruksional yang direncanakan oleh guru sebelumnya. Untuk mendapatkan hasil belajar tersebut siswa harus mengikuti pembelajaran dengan beberapa mata pelajaran baik itu pelajaran umum maupun pelajaran agama. $^{8}$

Berdasarkan pengamatan yang penulis lakukan selama Praktik Pengalaman Lapangan (PPL) pada tanggal 27 September 2016 terhadap proses belajar mengajar pada mata pelajaran Pendidikan Agama Islam (PAI) di kelas X AP3

${ }^{5}$ Suteja. Tafsir Tarbawi (Cirebon. Nurjati Press, 2015) hal. 127.

${ }^{6}$ Departemen Agama RI. Al-Hikmah (Bandung. Diponegoro, 2009) hal. 281. 2003), 101.

${ }^{7}$ Nana Syaodih, Landasan Psikologi Proses Pendidikan (Bandung: Remaja Rosdakarya,

${ }^{8}$ Popi Sopiatin dan Sohari Sahrani, Psikologi Belajar dalam Prespektif Islam (Bogor: Ghalia Indonesia, 2011), 63. 
SMK Veteran Cirebon, guru sudah berusaha maksimal dalam menyampaikan materi dengan baik, tetapi keinginan atau hasil belajar siswa masih kurang pada pembelajaran PAI dikarenakan metode yang diterapkan hanya ceramah yang menyebabkan siswa hanya duduk diam, mendengar, mencatat dan menghafal dan tidak dibiasakan untuk belajar aktif. Padahal secara teori, untuk lebih mengefektikan proses pembelajaran agar hasil belajar siswa meningkat, seharusnya menggunakan berbagai metode yang variatif.

Selain itu pada realitasnya, Peserta didik kurang mengamati pelajaran pada saat kegiatan belajar mengajar berlangsung, kurang dispilinnya peserta didik saat pembelajaran berlangsung, rendahnya partisipasi siswa dalam mengikuti pembelajaran di kelas. Begitupun wawancara dengan guru mata pelajaran PAI kelas X menyatakan bahwa Kriteria Ketuntasan Minimal (KKM) mata pelajaran PAI adalah 78 yang telah dimusyawarahkan semua guru dan disepakati oleh kepala sekolah. Namun pada kenyataannya masih ditemukan siswa yang memiliki nilai dibawah KKM. Inovasi yang terjadi berlangsung terlambat, khususnya siswa kelas X Administrasi Perkantoran (AP3) di Sekolah Menengah Kejuruan (SMK) Vetran Cirebon pada mata pelajaran PAI, yakni hasil nilai mata pelajaran PAI di kelas X AP3 lebih rendah dibandingkan dengan hasil nilai mata pelajaran lainnya, yang mana hasil nilai Ujian Tengah Semester (UTS) dari 28 peserta didik sekitar 15 peserta didik belum mencapai KKM (Kriteria Ketuntasan Minimal).

Salah satu upaya untuk meningkatkan proses belajar dan mengajar Pendidikan Agama Islam (PAI) agar lebih menarik siswa, guru dapat menggunakan metode picture and picture yang menggunakan alat gambar atau media berisi konsep materi yang akan di ajarkan oleh guru. Dengan menggunakan metode picture and picture siswa-siswi supaya lebih dapat memahami dan asyik dengan materi pelajaran Pendidikan Agama Islam (PAI).

Dari kajian masalah yang penulis temukan, kemudian dirumuskan permasalahannya, sehingga akan dihasilkan karya tulis yang baik. Adapun perumusan masalah sebagai berikut: 1). bagaimanakah penerapan metode picture and picture pada mata pelajaran PAI di kelas X AP3 Sekolah Menengah Kejuruan (SMK) Veteran Cirebon? 2). Adakah perbedaan hasil belajar siswa sebelum dan 
sesudah menerapkan metode picture and picture pada pembelajaran PAI dalam meningkatkan hasil belajar siswa kelas X AP3 Sekolah Menengah Kejuruan (SMK) Veteran Cirebon? 3). Adakah pengaruh penerapan metode Picture terhadap hasil belajar PAI siswa kelas X AP3 Sekolah Menengah Kejuruan (SMK) Veteran Kota Cirebon?

\section{B. PENERAPAN METODE PICTURE AND PICTURE DALAM MENINGKATKAN HASIL BELAJAR SISWA KELAS X AP3 PADA MATA PELAJARAN PENDIDIKAN AGAMA ISLAM}

\section{Metode Picture and Picture}

Metode menurut Arifin ${ }^{9}$ adalah suatu jalan yang dilalui untuk mencapai tujuan. Dalam bahasa arab metode disebut "thariqot." Dalam makna lain, metode pembelajaran diartikan sebagai prinsip-prinsip yang mendasari kegiatan mengarahkan perkembangan seseorang khususnya proses belajar mengajar.

Secara teknis metode berarti prosedur yang dipakai untuk mencapai tujuan, Metode juga diartikan sebagai prosedur yang dipergunakan pendidik dalam melaksanakan tugas-tugas kependidikan. Selain itu dapat juga diartikan sebagai teknik tertentu yang dipergunakan peserta didik untuk menguasai materi tertentu, atau cara yang dipakai untuk merumuskan aturan-aturan tertentu dari suatu prosedur. ${ }^{10}$ Menurut Suryono metode pembelajaran adalah seluruh perencanaan dan prosedur maupun langkah-langkah kegiatan pembelajaran termasuk pilihan cara penilaian yang akan dilaksanakan.

Dari pengertian di atas, dapat disimpulkan bahwa metode adalah cara atau jalan yang dipergunakan guru dalam menjalankan tugas kependidikannya. ${ }^{11}$

Adapun beberapa pertimbangan dalam memilih metode, yaitu:

1) Kesesuaian metode pembelajaran dengan tujuan pembelajaran.

${ }^{9}$ Ahmad N. Munjin dan Lilik Nur, Metode dan Teknik Pembelajaran Pendidikan Agama Islam (Bandung: Refika Aditama, 2009), 29.

${ }^{10}$ Suteja, Tafsir Tarbawi, 127.

${ }^{11}$ Suryono dan Hariyanto, Belajar dan Pembelajaran (Bandung: Rosdakarya, 2011), 19. 
2) Kesesuaian metode pembelajaran dengan materi pembelajaran.

3) Kesesuaian metode pembelajaraan dengan kemampuan guru.

4) Kesesuaian metode pembelajaran dengan kondisi siswa.

5) Kesesuaian metode pembelajaran dengan fasilitas tertentu.

6) Kesesuaian metode pembelajaran dengan situasi dan kondisi belajar mengajar.

Hamdayama pembelajaran Picture and Picture ini merupakan salah satu bentuk model pembelajaran kooperatif. Model pembelajaran kooperatif merupakan suatu model pembelajaran yang mengutamakan adanya kelompok-kelompok. Pembelajaran koperatif adalah pembelajaran yang secara sadar dan sistematis mengembangkan interaksi yang saling asah, silih asih, dan silih asuh. Metode Picture and Picture adalah suatu metode belajar yang menggunakan gambar dan dipasangkan/diurutkan menjadi urutan logis. $^{12}$

Menurut Ahmadi, Picture and Picture adalah suatu metode pembelajaran yang menggunakan gambar dan dipasangkan/diurutkan menjadi urutan logis. Picture and Picture ini berbeda dengan media gambar dimana Picture and Picture berupa gambar yang belum disusun secara berurutan dan yang menggunakannya adalah siswa, sedangkan media gambar berupa gambar utuh yang digunakan oleh guru dalam proses pembelajaran. Dengan adanya penyusunan gambar guru dapat mengetahui kemampuan siswa dalam memahami konsep materi dan melatih berfikir logis dan sistematis.

\section{Hasil Belajar}

Hasil belajar atau achievement merupakan realisasi atau pemekaran atau kecakapan-kecakapan potensial atau kapasitas yang dimilki seseorang.Penguasaan hasil belajar oleh seseorang dapat dilihat dari perilakunya, baik perilaku dalam bentuk penguasaan pengetahuaan, keterampilan berpikir maupun keterampilan motorik. ${ }^{13}$ Sedangkan menurut

12 Jumanta Hamdayama, Model dan Metode Pembelajaran Kreatif dan Berkarakter (Bogor: PT Ghalia Indonesia, 2014), 229.

${ }^{13}$ Nana Syaodih, Landasan Psikologi Proses Pendidikan, 101. 
Agus Suprijono hasil belajar atau output adalah pola-pola perbuatan, nilainilai, pengertian-pengertian, sikap-sikap, apresiasi dan keterampilan. ${ }^{14}$

Menurut Nana Sudjana hasil belajar adalah kemampuan yang dimiliki siswa setelah menerima pengalaman belajar. ${ }^{15}$ Sedangkan Wahidmurni, dkk. menjelaskan bahwa sesorang dapat dikatakan telah berhasil dalam belajar jika ia mampu menunjukkan adanya perubahan dalam dirinya. Perubahanperubahan tersebut di antaranya dari segi kemampuan berpikirnya, keterampilannya, atau sikapnya terhadap suatu objek.

Menurut Slameto "hasil belajar adalah sesuatu yang diperoleh dari suatu proses usaha setelah melakukan kegiatan belajar yang dapat diukur dengan menggunakan tes guna melihat kemajuan siswa". ${ }^{16}$ Senada dengan pendapat Rusman hasil belajar adalah sejumlah pengalaman yang diperoleh siswa yang mencakup ranah kognitf, apektif, dan psikomotorik. Belajar tidak hanya penguasaan kebiasaan, presepsi, kesenangan, minat-bakat, penyesuaian sosial, macam-macam keterampilan, cita-cita, keinginan dan harapan. Sedangkan menurut Oemar Hamalik dalam (Rusman, 2015: 67) hasil belajar itu dapat terlihat dari terjadinya perubahan dari presepsi dan perilaku, termasuk juga perubahan perilaku. Misalnya pemuasan kebutuhan masyarakat dan pribadi secara utuh. ${ }^{17}$

Menurut Gagne, ada lima kemampuan yang dikatakan sebagai hasil belajar yakni, keterampilan, intelektual, strategi kognitif, sikap, informasi verbal, dan keterampilan motorik. Tolak ukur keberhasilan siswa biasanya berupa nilai yang diperolehnya. Nilai itu diperoleh setelah siswa melakukan proses belajar dalam jangka waktu tertentu dan selanjutnya mengikuti tes akhir. Kemudian dari tes itulah guru menentukan prestasi belajar siswanya. ${ }^{18}$

\footnotetext{
${ }^{14}$ Agus Suprijono.2009. Cooperative Learning Teori dan Aplikasi PAIKEM (Yogyakarta: Pustaka Belajar, 2009), 5.

15 Nana Sudjana, Penilaian Hasil Proses Belajar Mengajar Cet. XV (Bandung: PT. Ramaja Rosdakarya, 2010), 22.

${ }^{16}$ Slameto, Proses Belajar Mengajar (Jakarta: Remaja Rosdakarya, 2008), 7.

${ }^{17}$ Rusman, Pembelajaran Tematik Terpadu (Jakarta: Rajagrafindo Persada, 2015), 67.

${ }^{18}$ Ratna Willis, Teori-teori Belajar \& Pembelajarn (Bandung: Erlangga, 2011), 118.
} 
Berdasarkan uraian di atas terkait teori tentang metode picture and picture dan hasil belajar. Maka untuk mengetahui jawaban dari permasalahan yang telah penulis sampaikan, penulis menentukan perihal metodologi penelitiannya. Penelitian jenis kuantitatif ini menggunakan desain penelitian eksperimen pre-test dan post test group, dengan teknik pengumpulan data observasi, angket, tes, wawancara dan dokumentasi. Adapun analisis datanya menggunakan rumus product moment dan SPSS Versi 16. Populasi dalam penelitian ini yaitu 113 siswa dan sampelnya sebanyak 28 siswa dengan menggunakan teknik pengambilan cluster sampling.

Untuk mengetahui hasil belajar siswa Sekolah Menengah Kejuruan (SMK) Veteran Kota Cirebon pada bidang studi PAI pokok bahasan materi meneladani perjuangan dakwah Rasulullah SAW di Madinah, penulis menggunakan tes formatif (ulangan harian) dengan menggunakan soal dalam bentuk pilihan ganda. Dalam pengambilan hasil belajar ini penulis menggunakan penialaian pretest dan posttest yang banyaknya disesuaikan dengan sampel yakni sebanyak 28 siswa kelas X-AP3, untuk lebih jelasnya berikut data pretest dan posttest.

\section{a. Deskripsi Data}

Penelitian dilakukan terhadap siswa kelas X Sekolah Menengah Kejuruan (SMK)Veteran Kota Cirebon dengan desain penelitian one group pretest-posttest design yakni dengan memberikan pretest dan posttest berupa tes berbentuk pilihan ganda sebanyak 25 dan uraian 5 butir.

Berdasarkan data pretest dan posttest yang telah diperoleh maka langkah selanjutnya penulis mengolah dan menganalisis data tersebut dalam aplikasi spss maka diperolehnya hasilnya sebagai berikut:

Tabel 4.26 Descriptive Statistics

\begin{tabular}{lrrrrr} 
& N & Minimum & Maximum & Mean & \multicolumn{2}{c}{ Std. Deviation } \\
\hline Pretest & 28 & 44 & 80 & 60.39 & 11.184 \\
Posttest & 28 & 78 & 92 & 87.18 & 4.099
\end{tabular}


Tabel 4.26 Descriptive Statistics

\begin{tabular}{lrrrrr}
\hline & N & Minimum & Maximum & Mean & \multicolumn{2}{c}{ Std. Deviation } \\
\hline Pretest & 28 & 44 & 80 & 60.39 & 11.184 \\
Posttest & 28 & 78 & 92 & 87.18 & 4.099 \\
Valid N & 28 & & & & \\
(listwise) & & & & & \\
\hline
\end{tabular}

Untuk mengetahui peningatan hasil belajar PAI siswa kelas X AP3 Sekolah Menengah Kejuruan (SMK) Veteran Kota Cirebon, peneliti menggunakan formula $N$-Gain.

Tabel 4.27 Descriptive Statistics

\begin{tabular}{|c|c|c|c|c|c|c|c|c|c|c|c|c|}
\hline & $\mathrm{N}$ & Range & $\begin{array}{c}\text { Minimu } \\
\mathrm{m}\end{array}$ & $\begin{array}{c}\text { Maxim } \\
\text { um }\end{array}$ & Mea & & $\begin{array}{c}\text { Std. } \\
\text { Deviation }\end{array}$ & Variance & Skewn & ness & \multicolumn{2}{|c|}{ Kurtosis } \\
\hline & & & & Statisti & & Std. & & & & Std. & & Std. \\
\hline & Statistic & Statistic & Statistic & $\mathrm{c}$ & Statistic & Error & Statistic & Statistic & Statistic & Error & Statistic & Error \\
\hline Pretest & 28 & 48 & 32 & 80 & 55.90 & 2.009 & 11.184 & 125.090 & -.009 & .421 & -.551 & .821 \\
\hline Posttest & 28 & 13 & 80 & 93 & 86.00 & .736 & 4.099 & 16.800 & .071 & .421 & -1.488 & .821 \\
\hline $\begin{array}{l}\text { Valid N } \\
\text { (listwise) }\end{array}$ & 28 & & & & & & & & & & & \\
\hline
\end{tabular}

Dari hasil analisis $\mathrm{N}$-gain diperoleh rata-rata peningkatan hasil belajar siswa di kelas X AP3 sebesar 0, 871 termasuk dalam kriteria tinggi.

\section{b. Analisa Data}

Sebelum uji hipotesis dilakukan, terlebih dahulu dilakukan uji normalitas dan uji homogenitas dua varians untuk mengetahui analisis lebih lanjut dari data gain kedua kelas tersebut.

a. Uji Normalisasi

Berikut ini adalah hasil normalitas gain dari hasil pretest dan posttst yakni sebelum menerapkan metode picture and picture dan sesudah menerapakan metode picture and picture pada pembelajaran PAI kelas X 
AP3 Sekolah Menengah Kejuruan (SMK) Veteran Kota Cirebon sebagai berikut:

Tabel 4.28 One-Sample Kolmogorov-Smirnov Test

\begin{tabular}{|c|c|c|c|}
\hline \multirow[b]{2}{*}{$\mathrm{N}$} & & Pretest & Posttest \\
\hline & & 28 & 28 \\
\hline \multirow[t]{2}{*}{ Normal Parameters $^{\mathrm{a}}$} & Mean & 68.96 & 87.18 \\
\hline & Std. Deviation & 7.696 & 4.047 \\
\hline Most Extreme & Absolute & .141 & .152 \\
\hline \multirow[t]{2}{*}{ Differences } & Positive & .112 & .117 \\
\hline & Negative & -.141 & -.152 \\
\hline \multicolumn{2}{|c|}{ Kolmogorov-Smirnov Z } & .745 & .804 \\
\hline \multicolumn{2}{|l|}{ Asymp. Sig. (2-tailed) } & .636 & .538 \\
\hline
\end{tabular}

Hipotesis:

$\mathrm{H}_{\mathrm{o}}$ : Data berdistribusi normal

$\mathrm{H}_{\mathrm{a}}$ : Data berdistribusi tidak normal

Kriteria pengujian:

Jika probabilitas (Sig.) > 0,05, $\mathrm{H}_{\mathrm{o}}$ diterima, artinya datanya normal.

Jika probabilitas (Sig.) < 0,05, $\mathrm{H}_{\mathrm{o}}$ ditolak, artinya data tidak normal.

Berdasarkan hasil uji normalitas diperoleh nilai sig. N-gain pretest dan posttest dengan uji Kolmogorov-Smirnov diperoleh 0,745 dan 0,804 berada di atas 0,05 , dengan demikian Ho diterima dan Ha ditolak. Artinya data yang penulis uji berdistribusi normal.

b. Uji Homogenitas

Uji homogenitas pada gain kedua data yaitu gain dari pretest dan posttest, berikut ini adalah hasil analisisnya:

Tabel 4.29 Test of Homogeneity of Variances

\begin{tabular}{rrrrrr}
\hline Levene Statistic & df1 & & df2 & \multicolumn{2}{c}{ Sig. } \\
\hline 1.785 & & 6 & & 11 & .192
\end{tabular}


Hipotesis :

$\mathrm{H}_{\mathrm{o}}$ : Kedua varian adalah sama (homogen)

$\mathrm{H}_{\mathrm{a}}$ : Kedua varian adalah berbeda (tidak homogen)

Kriteria pengujian:

Jika signifikansi (Sig,) > 0,05, H0 diterima, artinya data homogen.

Jika signifikasi $(\mathrm{Sig})<0,$,05 , H0 ditolak, artinya data tidak homogen.

Berdasarkam hasil uji homogenitas diketahui bahwa nilai rata-rata (based on mean) Sig, gain dari data pretest dan posttest semuanya berada di atas 0,05 yaitu 0,192. Maka Ho diterima dan Ha ditolak, artinya data berdistribusi homogen.

\section{Pengaruh Penerapan Metode Picture And Picture Pada Mata Pelajaran} PAI Untuk Meningkatkan Hasil Belajar Siswa Kelas X-AP3 Sekolah Menengah Kejuruan (SMK) Veteran Kota Cirebon

Berdasarkan untuk mengetahui pengaruh penerapan metode picture and picture siswa kelas X AP3 di Sekolah Menengah Kejuruan (SMK) Veteran Cirebon, penulis membuat dan membagikan sejumlah angket kepada siswa kelas X AP3 sebagai responden untuk memperoleh data varabel X yang telah diberi alternatif jawaban yaitu :

1. Jawaban selalu diberi nilai 4

2. Jawaban sering diberi nilai 3

3. Jawaban kadang-kadang diberi nilai 2

4. Jawaban tidak pernah diberi nilai 1

Adapun angket yang dibagikan yakni berjumlah 20 item. Bersumber dari 20 item angket tersebut penulis memperoleh keterangan atau data berdasarkan jawaban yang telah dipilih oleh siswa. Pada pengolahan penerapan metode picture and picture, peneliti mengklasifikasikan skor yang diperoleh dari angket yang telah dihitung dengan melihat paduan interpretasi angket.

Untuk menentukan hasil dari item tersebut, maka akan digunakan langkah-langkah sebagai berikut: 
1. Menentukan rata-rata: $\frac{\Sigma \bar{\chi}}{\text { Banyaknya item angket }}=\frac{69,25}{20}=3,46$

2. Menentukan kategori : $\frac{\text { Rata-rata }}{\text { Skor Maksimal }} \times 100 \%=\frac{3,46}{4} \times 100 \%=86,5 \%$

Berdasarkan rekapitulasi rata-rata hasil angket variabel $\mathrm{X}$ mengenai metode picture and picture pada mata pada pembelajaran PAI, maka dapat diambil kesimpulan bahwa penerapan metode picture and picture Sekolah Menengah Kejuruan (SMK) Veteran Kota Cirebon termasuk dalam kategori baik dengan nilai $86,5 \%$ karena berada pada interval $75 \%-100 \%$.

Untuk mengetahui ada atau tidaknya korelasi antara penerapan metode picture and picture terhadap hasil belajar pada bidang studi PAI kelas X AP3 di Sekolah Menengah Kejuruan (SMK) Veteran kota Cirebon dapat diketahui dengan menggunakan teknik analisa statistik "Koefesien Korelasi Person atau Product Moment". Untuk penghitungan korelasi maka peneliti akan menyajikan data variable (X) dan Variable (Y). Variable (X) adalah penerapan metode picture and picture sedangkan Variable (Y) adalah Hasil Belajar siswa pada bidang studi PAI.

Perhitungan korelasi antara penerapan metode picture and picture dan hasil belajar siswa (Y) yang menunjukan positif dan tidaknya dalam korelasi tersebut, telah dianalisis melalui table berikut ini :

Tabel 4. 30

Perhitungan korelasi Product Moment antara penerapan metode picture and picture (Variabel X) dengan hasil belajar siswa kelas X AP3 (Variabel Y) Sekolah Menengah Kejuruan (SMK) Veteran Kota Cirebon

\begin{tabular}{cccccc}
\hline NO & $\mathbf{X}$ & $\mathbf{Y}$ & $\mathbf{X 2}$ & $\mathbf{Y 2}$ & $\mathbf{X Y}$ \\
\hline 1 & 51 & 88 & 2601 & 7744 & 4488 \\
2 & 69 & 90 & 4761 & 8100 & 6210 \\
3 & 76 & 92 & 5776 & 8464 & 6992 \\
4 & 51 & 80 & 2601 & 6400 & 4080 \\
5 & 68 & 92 & 4624 & 8464 & 6256 \\
6 & 65 & 78 & 4225 & 6084 & 5070 \\
7 & 59 & 80 & 3481 & 6400 & 4720 \\
8 & 73 & 92 & 5329 & 8464 & 6716
\end{tabular}




$\begin{array}{cccccc}9 & 74 & 90 & 5476 & 8100 & 6660 \\ 10 & 66 & 88 & 4356 & 7744 & 5808 \\ 11 & 72 & 85 & 5184 & 7225 & 6120 \\ 12 & 68 & 88 & 4624 & 7744 & 5984 \\ 13 & 62 & 87 & 3844 & 7569 & 5394 \\ 14 & 64 & 86 & 4096 & 7396 & 5504 \\ 15 & 59 & 84 & 3481 & 7056 & 4956 \\ 16 & 68 & 92 & 4624 & 8464 & 6256 \\ 17 & 77 & 88 & 5929 & 7744 & 6776 \\ 18 & 75 & 92 & 5625 & 8464 & 6900 \\ 19 & 62 & 84 & 3844 & 7056 & 5208 \\ 20 & 77 & 90 & 5929 & 8100 & 6930 \\ 21 & 70 & 86 & 4900 & 7396 & 6020 \\ 22 & 76 & 89 & 5776 & 7921 & 6764 \\ 23 & 76 & 88 & 5776 & 7744 & 6688 \\ 24 & 76 & 85 & 5776 & 7225 & 6460 \\ 25 & 67 & 80 & 4489 & 6400 & 5360 \\ 26 & 75 & 88 & 5625 & 7744 & 6600 \\ 27 & 76 & 87 & 5776 & 7569 & 6612 \\ 28 & 79 & 92 & 6241 & 8464 & 7268 \\ \text { Jumlah } & 1931 & 2441 & 134769 & 213245 & 168800\end{array}$

Berdasarkan tabel di atas, maka dapat diketahui bahwa :

$$
\begin{aligned}
& \mathrm{N}=28 \\
& \sum y 2=213245 \\
& \sum x=1931 \\
& \sum x y=168800 \\
& \sum y=2441 \\
& \sum x^{2}=134769
\end{aligned}
$$

Data telah didapat dalam bentuk angket dan tes tadi, selanjutnya diolah menggunakan perhitungan korelasi Spearmen atau yang sering disebut dengan korelasi Product Moment, hal ini digunakan untuk mengetahui apakah terdapat korelasi antara variabel $\mathrm{X}$ dan variabel $\mathrm{Y}$ atau tidak. Adapun perhitungan rumusnya sebagai berikut : 


$$
\begin{aligned}
& r_{x y}=\frac{N \sum x y-\left(\sum x\right)\left(\sum y\right)}{\sqrt{\left.\left\{N \sum x^{2}-\left(\sum x\right)^{2}\right\} N \sum y^{2}-\left(\sum y\right)^{2}\right\}}} \\
& =\frac{28.168800-(1931)(2441)}{\sqrt{\left\{28 \sum 134769-(1931)^{2},\left\{28 \sum 213245-(2441)^{2}\right\}\right.}} \\
& =\frac{4.726 .400-4.713 .571}{\sqrt{\sqrt{\{3.773 .532-3.728 .761\}\{5.970 .860-5.958 .481\}}}} \\
& =\frac{12.829}{\sqrt{(44.771)(12.379)}} \\
& =\frac{12.829}{23.541} \\
& =0.544
\end{aligned}
$$

Menurut Anas Sudjiono dalam memberikan interpretasi secara sederhana terhadap Angka Indeks Korelasi " $r$ " Product Moment $\left(\mathrm{r}_{\mathrm{xy}}\right)$, pada umumnya dipergunakan pedoman atau ancar-ancar sebagai berikut:

Tabel.4.31

Angka Indeks Korelasi “r” Product Moment $\left(\mathrm{r}_{\mathrm{xy}}\right)$

\begin{tabular}{cl}
\hline $\begin{array}{c}\text { Besarnya " } r \text { "Product Moment } \\
\left(\mathrm{r}_{\mathrm{xy}}\right)\end{array}$ & \multicolumn{1}{c}{ Interpretasi } \\
\hline $0,00-0,20$ & Antara variabel $\mathrm{X}$ dan variable $\mathrm{Y}$ \\
& memang terdapat korelasi, akan tetapi \\
& korelasi itu sangat lemah atau sangat \\
& rendah sehingga korelasi itu \\
& diabaikan (dianggap tidak adakorelasi \\
& antara variabel X dan variabel Y). \\
& Antara variabel $\mathrm{X}$ dan variabel Y \\
& terdapat korelasi yang lemah atau \\
& rendah. \\
& Antara variabel $\mathrm{X}$ dan variabel Y \\
$0,40-0,70$ &
\end{tabular}


terdapat korelasi yang sedang atau

cukup.

$0,70-0,90 \quad$ Antara variabel $\mathrm{X}$ dan variabel $\mathrm{Y}$ terdapat korelasi yang kuat atau tinggi.

Antara variabel $\mathrm{X}$ dan variabel $\mathrm{Y}$

$0,90-1,00$ terdapat korelasi yang sangat kuat atau sangat tinggi.

Berdasarkan hasil perhitungan di atas, diperoleh nilai koefisien antara metode picture and picture (variabel $\mathrm{x}$ ) terhadap Hasil Belajar siswa pada pembelajaran PAI (variabel y) sebesar $r_{x y}=0,544$. Hasil tersebut apabila dirubah kedalam skala konservati, 0554 berada pada interval 0,400,70 yang berarti memiliki tingkat korelasi yang sedang atau cukup.

Perhitungan di atas memiliki $\mathrm{r}_{\mathrm{xy}}$ sebesar $=0,544$, dan angka indeks korelasi tersebut bertanda positif, sehingga korelasi antara variabel $\mathrm{x}$ dan variabel y memiliki hubungan yang searah, atau dengan kata lain terdapat korelasi positif antara kedua variabel tersebut.

Nilai signifikansi dari perhitungan di atas, dapat dicari dengan membandingkan dengan nilai pada $\mathrm{r}$ tabel, namun sebelumnya harus dicari terlebih dahulu derajat bebasnya (db) atau degrees of freedom (df). Rumusnya adalah $\mathrm{db}=\mathrm{N}-\mathrm{nr}$ atau $\mathrm{db}=28-2=26$, maka dapat diketahui nilai $r$ tabel pada $n=26$ adalah sebesar 0,388 dengan taraf kesalahan 5\%, maka dapat diuraikan sebagai berikut :

Hipotesis:

$\mathrm{H}_{0}$ : Data Signifikan

$\mathrm{H}_{\mathrm{a}}$ : Data Tidak Signifikan

Kriteria Pengujian:

Jika nilai $\mathrm{r}$ hitung > r tabel, H0 diterima, artinya data signifikan

Jika nilai $r$ hitung < r tabel, Ha ditolak, artinya data tidak signifikan

Berdasarkan hasil $\mathrm{r}$ hitung di atas, maka dapat diketahui bahwa nilai $r$ hitung $=0,544$ dan $r$ tabel sebesar $=0,388$, maka dapat disimpulkan 
bahwa nilai $\mathrm{r}$ hitung $>$ dari $\mathrm{r}$ tabel, oleh karena itu hubungan antara penerapan metode picture and picture (variabel $\mathrm{x}$ ) dan hasil belajar (variabel y) dinyatakan signifikan secara statistik, berarti semakin tinggi atau semakin baik penerapan metode picture and picture (variabel $\mathrm{x}$ ) akan berhubungan secara langsung dengan semakin baiknya hasil belajar (variabel y) dan sebaliknya, ketika penerapan metode picture and picture (variabel $\mathrm{x}$ ) turun atau rendah maka akan berhubungan dengan rendahnya hasil belajar (variabel y). Dengan demikian bahwa terdapat hubungan yang positif dan signifikan antara metode picture and picture dalam meningkatkan hasil belajar siswa pada pembelajaran PAI di Sekolah Menengah Kejuruan (SMK) Veteran Kota Cirebon. Dengan demikian dapat disimpulkan bahwa dengan adanya uji signifikansi, maka hasil yang didapat dari sampel ini tidak dapat digenaralisasikan untuk semua populasi yang ada.

Nilai korelasi dari hasil perhitungan di atas, selanjutnya dihitung nilai koefisien determinasinya, untuk mengetahui apakah ada pengaruh antara metode picture and picture (variabel $\mathrm{x}$ ) dengan hasil belajar siswa pada pembelajaran PAI (variabel y), rumusnya sebagai berikut :

$$
\begin{aligned}
\mathrm{KD} & =r^{2} \times 100 \% \\
& =0,5449^{2} \times 100 \% \\
& =0,296916 \times 100 \% \\
& =0,296916 \%
\end{aligned}
$$

Hasil dari koefisien determinasi di atas, menunjukan bahwa pengaruh metode picture and picture untuk meningkatkan hasil belajar siswa pada pembelajaran PAI di Sekolah Menengah Kejuruan (SMK) Veteran Kota Cirebon Ssebesar 29,69\%. Dengan diperoleh koefisien determinasi (KD) sebesar 29,69\%, maka dapat disimpulkan bahwa 100\% $29,69 \%=70,31 \%$. Dengan demikian koefisien determinasi (KD) sebesar $70,31 \%$ hasil belajar itu tidak hanya berkaitan dengan penerapan metode picture and picture tetapi dipengaruhi oleh faktor lain. Dapat disimpulkan bahwa hasil belajar siswa tidak hanya berhubungan dengan penerapan 
metode picture and picture akan tetapi juga berhubungan dengan kecerdasan anak, disiplin, kemampuan guru, vasilitas belajar, lingkungan, teman, masyarakat dan lainnya.

Berdasarkan hasil perhitungan di atas diperoleh $r_{x y}=0.544$, dalam hal ini, nilai $r_{x y}$ diartikan sebagai koefesien validitas berada pada rentang 0,40-0,70 dengan korelasi sedang atau cukup. Untuk menguji kebenaran atau kepalsuan dari hipotsis yang telah penulis ajukan bab I sebelumnya, maka penulis membandingkan besarnya " $\mathrm{r}$ " product moment, dengan terlebih dahulu mencari derajar bebasnya $(\mathrm{db})$ atau degrees of freedom nya (df) yang rumusnya sebagai berikut:

$\mathrm{df}=\mathrm{N}-\mathrm{Nr}$

Keterangan:

$\mathrm{df}=$ Degrees of freedom

$\mathrm{N}=$ Jumlah responden

$\mathrm{Nr}=$ Banyaknya variabel yang dikorelasikan

Penelitian ini degrees of freedom nya adalah $\mathrm{df}=28-2=26$. Dengan diperoleh db atau df maka dapat kita cari besarnya "r" yang terdapat dalam tabel nilai "r" product moment. Baik pada taraf signifikansi $95 \%$ maupun pada taraf signifikansi 100\%. Setelah diketahui db atau df sebesar 26. Maka penulis mengambil db atau df pada penelitian ini sebesar 26.

Maka pada tabel nilai-nilai "r" product moment dapat diketahui pada taraf signifikansi $95 \%$ harga " $\mathrm{r}$ " adalah 0,544 dan pada taraf signifikansi $99 \%$ adalah 0,496. Karena $\mathrm{r}_{\text {observasi }}$ " $\mathrm{r}_{\mathrm{o}}$ " lebih besar dari " $\mathrm{r}_{\text {tabel }}$ " " $\mathrm{r}_{\mathrm{t}}$ ", pada taraf signifikansi $95 \%(0,544>0,388)$, maka $\mathrm{H}_{\mathrm{a}}$ menyatakan bahwa terdapat korelasi positif yang signifikan antara penerapan metode picture and picture dalam meningkatkan hasil belajar siswa kelas X AP3 pada pembeajaran PAI Sekolah Menengah Kejuruan (SMK) Veteran Kota Cirebon diterima. Sedangkan Ho yang menyatakan bahwa tidak terdapat korelasi positif yang signifikan antara metode picture and picture dalam meningkatkan hasil belajar siswa pada pembeajaran PAI Sekolah Menengah Kejuruan (SMK) Veteran Kota Cirebon ditolak. 
Hasil perhitungan di atas, dapat dikemukakan bahwa terdapat korelasi yang positif antara penerapan metode picture and picture dengan hasil belajar siswa dengan jumlah 29,69\% sedangkan sisanya 70,31\% dipengaruhi faktor lain, seperti kecerdasan anak, disiplin, kemampuan guru, vasilitas belajar, lingkungan, teman, masyarakat dan lainnya.

Setelah diketahui koefisien korelasi di atas, maka dapat diketahui nilai $t_{\text {hitung }}$ sebagai berikut:

$$
\begin{aligned}
t_{\text {hitung }} & =\frac{r \sqrt{n-2}}{\sqrt{1-r^{2}}} \\
t_{\text {hitung }} & =\frac{0,544 \sqrt{28-2}}{\sqrt{1-0,544^{2}}} \\
& =\frac{0,544 \sqrt{26}}{\sqrt{1-0,295936}} \\
& =\frac{(0,544)(5,009)}{\sqrt{1-0,295936}} \\
& =\frac{2,724896}{0,83} \\
& =3,283
\end{aligned}
$$

Mencari t Tabel dengan $\alpha=0,01$

$\mathrm{df}=(\mathrm{n}=2=28-2)=26$

$26=2,77$

Maka $: \mathrm{t}$ hitung $=3,283>\mathrm{t}$ tabel $=2,778$

Berdasarkan perhitungan dari $t$ hitung, bahwasannya $t$ hitung $(3,283)>$ $t$ table $(2,778)$ maka,uji hipotesis menjawab $\mathrm{H}_{\mathrm{a}}$ diterima dan $\mathrm{H}_{\mathrm{o}}$ ditolak. Artinya hipotesis yang menjawab bahwa adanya pengaruh yang signifikan antara penerapan metode picture and picture dalam meningkatkan hasil belajar siswa kelas X AP3 pada mata pelajaran PAI Sekolah Menengah Kejuruan (SMK) Veteran Kota Cirebon adalah diterima. 


\section{c. Kesimpulan}

Berdasarkan hasil penelitian tentang penerapan metode picture and picture untuk meningkatkan hasil belajar siswa pada mata pelajaran PAI kelas X AP3 Sekolah Menengah Kejuruan (SMK) Veteran Cirebon yang telah dilakukan dapat disimpulkan sebagai berikut :

1. Penerapan metode picture and picture pada mata pelajaran PAI kelas X AP3 Sekolah Menengah Kejuruan (SMK) Veteran Cirebon termasuk dalam kategori baik dengan nilai 86,5\% karena berada pada interval 75\% $100 \%$.

2. Hasil belajar yang diperoleh siswa-siswi kelas X AP3 Sekolah Menengah Kejuruan (SMK) Veteran Cirebon padamata pelajaran PAI dengan pokok bahasan strategi dakwah Rasulullah di Madinah sebelum diterapkannya metode picture and picture termasuk dalam kategori sedang atau cukup hal ini ditunjukan dengan rata-rata nilai adalah 60 yang berada pada interval $60 \%-70 \%$.

Hasil belajar yang diperoleh siswa kelas X AP3 Sekolah Menengah Kejuruan (SMK) Veteran Cirebon pada mata pelajaran PAI dengan pokok bahasan strategi dakwah Rasulullah di Madinah sesudah diterapkannya metode picture and picture termasuk dalam kategori sangat tinggi hal ini ditunjukan dengan rata-rata nilai adalah 87 yang berada pada interval $87 \%-100 \%$.

3. Berdasarkan hasil pengujian angket dan tes, terdapat pengaruh yang positif antara penerapan metode picture and picture dengan hasil belajar siswa pada mata pelajaran PAI kelas X AP3 Sekolah Menengah Kejuruan (SMK) Veteran Cirebon. Dan korelasi ini dikategorikan sedang atau cukup dikarenakan ${ }^{\mathrm{t}}$ hitung sebesar 0,544 ternyata terletak pada interval 0,40 - 0,70. Berdasarkan kriteria tersebut maka makna koefisien korelasi termasuk ke dalam kategori korelasi yang sedang atau cukup.

Adapun besaran pengaruh penerapan metode picture and picture terhadap hasil belajar siswa pada mata pelajaran PAI kelas X AP3 Sekolah Menengah Kejuruan (SMK) Veteran Cirebon sebesar 29.69\%, sedangkan 
sisanya 70,31\% dipengaruhi faktor lain, seperti kecerdasan anak, disiplin, kemampuan guru, vasilitas belajar, lingkungan, teman, masyarakat dan lainnya yang tidak diteliti.

Berdasarkan perhitungan dari $t$ hitung, bahwasannya $t$ hitung $(3,283)>$ $t$ tabel $(2,778)$, makauji hipotesis menjawab $\mathrm{H}_{\mathrm{a}}$ diterima dan $\mathrm{H}_{\mathrm{o}}$ ditolak. Artinya hipotesis yang menjawab bahwa ada pengaruh antara metode picture and picture dalam meningkatkan hasil belajar siswa pada mata pelajaran PAI kelas X AP3 Sekolah Menengah Kejuruan (SMK) Veteran Cirebon adalah diterima. 


\section{DAFTAR PUSTAKA}

Aunurrahman, 2009. Belajar dan pembelajaran. Pontianak: ALFABETA.

Departemen Agama RI. 2009. Al-Hikmah. Bandung. Diponegoro.

Hamdayama, Jumanta, 2014. Model dan Metode Pembelajaran Kreatif dan Berkarakter Bogor: PT Ghalia Indonesia.

Munjin N. Ahmad dan Lilik Nur, 2009. Metode dan Teknik Pembelajaran Pendidikan Agama Islam. Bandung: Refika Aditama.

Rusman, 2015. Pembelajaran Tematik Terpadu. Jakarta: Rajagrafindo Persada.

Slameto, 2008. Proses Belajar Mengajar. Jakarta: Remaja Rosdakarya.

Sopiatin, Popi dan Sohari Sahrani, 2011. Psikologi Belajar dalam Prespektif Islam

Bogor: Ghalia Indonesia.

Sudjana, Nana, 2010. Penilaian Hasil Proses Belajar Mengajar Cet. XV Bandung: PT. Ramaja Rosdakarya.

Suprijono, Agus, 2009. Cooperative Learning Teori dan Aplikasi PAIKEM Yogyakarta: Pustaka Belajar.

Suryono dan Hariyanto, 2011. Belajar dan Pembelajaran. Bandung: Rosdakarya.

Suteja, 2015. Tafsir Tarbawi. Cirebon. Nurjati Press.

Syaodih, Nana, 2003. Landasan Psikologi Proses Pendidikan. Bandung: Remaja

Rosdakarya.

Trianto, 2009. Mendesain model pembelajaran inovatif-progresif. Jakarta: PT Prenada Media Group.

Trianto, 2011. Mendesain Model Pembelajaran Inovatif-Progresif. Jakarta: Kencana.

Undang-undang SISDIKNAS (Sistem Pendidikan Nasional ) no 20 Th 2003. 2011. Jakarta.: Sinar Grafika.

Willis, Ratna, 2011. Teori-teori Belajar \& Pembelajarn. Bandung. Erlangga. 